\title{
Review of the Inca irroratus species group with description of two new species of Inca LePeletier \& Serville, 1828 (Coleoptera, Scarabaeidae, Cetoniinae)
}

\author{
Rafael SOUSA ${ }^{1} \&$ Matthias SEIDEL ${ }^{2, *}$ \\ ${ }^{1}$ Museu de Zoologia da Universidade de São Paulo, Avenida Nazaré 481, \\ Ipiranga, 04263-000 São Paulo, São Paulo, Brazil. \\ ${ }^{2}$ Centrum für Naturkunde, University of Hamburg, Martin-Luther-King-Platz 3, \\ 20146, Hamburg, Germany. \\ *Corresponding author: matthias.seidel@uni-hamburg.de \\ ${ }^{1}$ E-mail: rafael.souza1988@gmail.com \\ ${ }^{1}$ urn:1sid:zoobank.org:author:3A67BC42-1B90-4D6C-A1EA-EB40FA131EA6 \\ ${ }^{2}$ urn:1sid:zoobank.org:author:4DD9F954-99BB-49E9-AF45-D35E6D8903E3 \\ $1 \odot$ https://orcid.org/0000-0001-9394-522X \\ $2 \odot$ https://orcid.org/0000-0002-4913-8778
}

\begin{abstract}
The Brazilian endemic irroratus species group of the genus Inca (Scarabaeidae, Cetoniinae) is defined and described. This species group is composed of Inca irroratus Chevrolat, 1833 and two new species: I. axeli sp. nov. and I. neglectus sp. nov. One new synonym is proposed: I. irroratus Chevrolat, $1833=$ I. burmeisteri Burmeister, 1844 syn. nov. To guarantee nomenclatural stability, a neotype is designated for I. irroratus and a lectotype for I. burmeisteri. A key to all species of Inca and a map with the distribution of the irroratus species group are provided.
\end{abstract}

Keywords. Atlantic Forest, flower chafers, Incini, Neotropical, taxonomy, synonym.

Sousa R. \& Seidel M. 2021. Review of the Inca irroratus species group with description of two new species of Inca LePeletier \& Serville, 1828 (Coleoptera, Scarabaeidae, Cetoniinae). European Journal of Taxonomy 748: 15-35. https://doi.org/10.5852/ejt.2021.748.1335

\section{Introduction}

Incini Burmeister, 1842 (Coleoptera Linnaeus, 1758, Scarabaeidae Latreille, 1802, Cetoniinae Leach, 1815) is a Neotropical tribe of flower chafers and includes five genera (Seidel et al. 2018): Archedinus Morón \& Krikken, 1990, Coelocratus Burmeister, 1842, Golinca Thomson, 1878, Inca LePeletier \& Serville, 1828, and Pantodinus Burmeister, 1847.

Krikken (1984) elevated Incini to the status of tribe and included the genera Inca and Golinca, previously placed in Osmodermatini Schenkling, 1922 by Schenkling (1921, 1922), and Archedinus 
and Pantodinus. Krikken (1984) included Coelocratus in Trichiini Fleming, 1821 which was later transferred by Ricchiardi (2002) to 'Incaini'. The nomenclatural change of Incaini to the correct spelling Incini was proposed by Bouchard et al. (2011) and further commented on by Seidel et al. (2018). After Krikken, many studies on taxonomy, phylogeny and biology of larvae and adults of Incini were made (Costa et al. 1988; Morón \& Vaz-de-Mello 2007; Micó et al. 2008; Šípek et al. 2009, 2012, 2016; Sousa et al. 2018; Seidel et al. 2018; Tauzin \& Arnaud 2019).

Ohaus (1900) was one of the first to provide biological notes on immatures of Incini. Afterwards, other works added data about larva and pupa (Morón 1983, 1995; Costa et al. 1988; Sousa et al. 2018).

Phylogenetic studies based on morphological and molecular data of immature stages and adults of some species recovered the tribe as monophyletic (Morón \& Vaz-de-Mello 2007; Micó et al. 2008; Šípek et al. 2009, 2012, 2016).

Tauzin \& Arnaud (2019) provided remarks on the genera Inca and Golinca and presented a study on biology and distribution of species. Tauzin \& Arnaud (2019) updated data on species occurrence, but did not include information formerly made available in several studies (e.g., Morón 1983; Di Iorio 2013; Seidel et al. 2018). The authors also presented a discussion on the larval stage of species of Inca and data on the life cycle of I. bonplandi (Gyllenhal, 1817), I. clathratus sommeri Westwood, 1844, and I. pulverulentus (Olivier, 1789), but omitted recent morphological studies that compare the structures and chaetotaxy of third-instar larva of these species (Morón 1983, 1995; Costa et al. 1988; Sousa et al. 2018). Moreover, they proposed the synonymy of Incini with Osmodermatini based on general similarities of life cycle and on morphology of Osmoderma and Inca. The synonymy proposed did not take into account the diagnoses given by Krikken (1984) (i.e., eye-canthus angulated in front, profemur with a distal tooth in the inner area and protibia with internal face with proximal emargination) and the phylogenetic hypotheses already proposed (Morón \& Vaz-de-Mello 2007; Micó et al. 2008; Śípek et al. 2009, 2016; Š́pek \& Král 2012).

Currently, the genus Inca includes 6 species and 3 subspecies (Seidel et al. 2018): I. besckii Burmeister \& Schaum, 1840, I. bonplandi (Gyllenhal, 1817), I. burmeisteri Burmeister 1847, I. clathratus clathratus (Olivier, 1792), I. clathratus quesneli Boos \& Ratcliffe, 1985, I. clathratus sommeri Westwood, 1844, I. irroratus Chevrolat, 1833, and I. pulverulentus (Olivier, 1789).

The taxonomic history of the newly defined irroratus group (see Results) is complicated, leading to most museum specimens being misidentified. Chevrolat (1833) described I. irroratus based on a female specimen recorded from Rio de Janeiro State, Brazil which was subsequently illustrated by Gory \& Percheron (1833) in the same year.

Burmeister (1842) described the male of I. irroratus, however later (Burmeister 1847) claiming that this was based on a misidentification stated: "Inca irroratus. Page 708. -Under this name 2 species are united, which I received in the previous year both directly from Brazil from Mr. Bescke and thus learned to differentiate safely. Mr. Bescke had recognized their differences very well, and the one, if it should still be undescribed, was given my name. I let them follow here under this name". Subsequently, Burmeister (1847) described Inca burmeisteri updating his 1842 redescription to this new species. Furthermore, he redescribed Inca irroratus based on the material of the second species provided by Bescke. After studying the description by Chevrolat (1833) and the illustration by Gory \& Percheron (1833), we conclude that Burmeister's (1842) description of Inca irroratus was indeed correct and therefore leading to I. burmeisteri becoming a junior synonym of that species. Inca irroratus sensu Burmeister (1847) is therefore still an unnamed species that we here describe as Inca neglectus sp. nov. 
All species of Inca are distributed in Brazil, however species of the irroratus group are so far only known from Nova Friburgo, Rio de Janeiro State, Ouro Preto, and Minas Gerais State (Seidel et al. 2018). The distribution of species of Inca and our knowledge on the morphology of the genus will be expanded in this work, which describes an additional new species I. axeli sp. nov. that occurs in the southern and southeast region of Brazil in Paraná, Santa Catarina and São Paulo States (Fig. 5). Moreover, for the first time a key to all the species of the genus is provided.

Finally, we recognize that certain species of Inca share sets of distinct morphological characters, and will be therefore distributed in three different species groups: bonplandi group (I. bonplandi, I. besckii), clathratus group (I. clathratus clathratus, I. clathratus quesneli, I. clathratus sommeri, I. pulverulentus) and irroratus group (I. axeli sp. nov., I. irroratus, I. neglectus sp. nov.).

\section{Material and methods}

\section{Collections}

The material cited is deposited in the following collections (curator(s) in parentheses):

BMNH $=$ Natural History Museum (formerly British Museum, Natural History), London, UK (Maxwell V. L. Barclay, Michael Geiser)

CEMT = Setor de Entomologia da Coleção Zoológica, Universidade Federal do Mato Grosso, Cuiabá, Brazil (Fernando Vaz de Mello)

MLUH = Zentralmagazin Naturwissenschaftlicher Sammlungen, Martin-Luther-Universität Halle Wittenberg, Halle, Germany (Karla Schneider, Joachim Händel)

MNHN = Muséum national d'histoire naturelle, Paris, France (Antoine Mantilleri, Olivier Montreuil)

MSPC = Matthias Seidel Personal Collection, Hamburg, Germany

MZSP = Museu de Zoologia da Universidade de São Paulo, São Paulo, Brazil (Sonia A. Casari)

RBINS = Royal Belgian Institute of Natural Sciences, Brussels, Belgium (Alain Drumont)

SMNS = Staatliches Museum für Naturkunde, Stuttgart, Germany (Arnaud Faille)

UFRPE $=$ Coleção Entomológica, Universidade Rural de Pernambuco, Recife, Brazil (Paschoal Grossi)

$\mathrm{ZMH}=$ Zoologisches Museum, Centrum für Naturkunde, Hamburg, Germany (Matthias Seidel, Martin Husemann)

\section{Illustrations}

Photographs were taken with a Canon EOS 80D DSLR camera with a Canon MP-E $65 \mathrm{~mm} \mathrm{f} / 2.8$ and Canon Ef $50 \mathrm{~mm} \mathrm{F/1.8} \mathrm{Stm} \mathrm{lens} \mathrm{and} \mathrm{processed} \mathrm{using} \mathrm{Zerene} \mathrm{stacker} \mathrm{(Zerene} \mathrm{systems} \mathrm{LLC,} \mathrm{Richland,}$ Washington, United States of America). The maps were made using the software ArcMap ver. 10.5 (Esri 2016, ArcGIS Desktop ver. 10.5). Plates were made using the software Adobe Illustrator CC 2018 and Adobe Photoshop CC 2018. All original unedited photographs and additional SEM micrographs of adults of specimens were uploaded as a .zip file to the Zenodo depository under https://zenodo.org/10.5281/zenodo.4681721.

\section{Terminology}

The general terminology of structures follows Beutel \& Lawrence (2005) updated by Lawrence et al. (2010). The terminology of the clypeal horns is adapted from Bates (1889) and Boos \& Ratcliffe (1985). Because of the evidence presented by Š́pek et al. (2016), this study does not follow the synonymy proposed by Tauzin \& Arnaud (2019), and follows the tribal classifications presented by Krikken (1984) and Seidel et al. (2018), that consider Incini and Osmodermatini as two different tribes. 


\title{
Results
}

\author{
Phylum Arthropoda Latreille, 1829 \\ Class Insecta Linnaeus, 1758 \\ Order Coleoptera Linnaeus, 1758 \\ Superfamily Scarabaeoidea Latreille, 1802 \\ Family Scarabaeidae Latreille, 1802 \\ Subfamily Cetoniinae Leach, 1815 \\ Tribe Incini Burmeister, 1842
}

Genus Inca LePeletier \& Serville, 1828

Inca LePeletier \& Serville, 1828: 380.

Ynca-Chevrolat 1833: unpaginated (unjustified emendation).

Inca-Seidel et al. 2018: 389 (checklist, nomenclature).

\section{Type species}

Cetonia ynca Weber, 1801, designated by Howden (1968: 12).

\section{Diagnosis}

The genus can be distinguished from other genera of Incini by the following combination of characters: dorsal surface of pronotum covered with waxy velvet like secretion and setigerous punctures with waxy macula (waxy secretion absent in Archedinus, Coelocratus, Golinca and Pantodinus); clypeus of male with divergent lateral horns (parallel horns in Golinca; median horn in Pantodinus; absent in Archedinus and Coelocratus) with inner area densely setose.

\section{Redescription}

\section{Male}

BoDy. Length including the clypeal horns $23-60 \mathrm{~mm}$; width across humeri $10-21 \mathrm{~mm}$. Surface of pronotum, scutellar shield, elytra and pygidium covered with waxy, velvet like secretion and setigerous punctures with waxy macula.

Head. Surface of frons with waxy secretion on disc and setigerous and heterogeneous punctures with light yellow waxy macula; short yellowish setae near to supraocular area; lateral portion of epistomal suture distinct near to canthus. Canthus angulate. Clypeus densely punctate with posterior dorsal margin projecting forward; distal area with divergent lateral horns slightly projecting forward and upward; inner area of horns densely setose, setae long and yellow. Labrum transverse. Mandibles with molar lobe rounded and striated; right molar lobe convex; left molar lobe concave. Maxillae setose; cardo with proximal area densely punctate with long yellow setae; galea inwards projected and with brushlike setae. Hypopharynx with long setae. Labium transverse, deeply and densely punctate; punctures with long yellow setae; anterior margin of mentum emarginated. Antennae with 10 antennomeres; club fusiform composed of three antennomeres.

Thorax. Pronotal surface convex, disc with a longitudinal groove; densely punctate and with short yellow setae; lateral margin sinuated and irregularly crenulated. Hypomeron densely punctate; anterior area with irregular striated punctures. Anterior prosternal process projected (except in I. besckii and I. bonplandi). Metaventrite densely setose except in the discrimen area. Elytra densely punctate and maculate; elytral striae barely distinct; distal angle acuminate. 
LeGs. Profemur with an inner distal tooth. Protibia with a posterior distal tooth and an inner proximal emargination; spur short. Protarsomeres II-IV with inner striae. Mesotibia with one short and bifurcate spur; transversal carina I with stout setae. Outer posterior angle of metacoxa rounded. Metatibia with transversal carina I with stout setae.

Aвdomen. Spiracle VII placed near to anterior margin of sternite. Sternite VIII (last exposed sternite) with a rounded fovea on anteriomedian area. Propygidium totally or partially covered by resting elytra. Pygidium posterior margin parabolic.

Terminalia. Aedeagus: apodeme of phallobase larger than phallobase. Parameres glabrous and with an outer distal process.

\section{Female}

BoDy. Length 27-50 mm; width across humeri 10-17 mm. The morphology of females of Inca is very similar to the male, except by: posterior area of frons with waxy secretion. Clypeus without horns; anterior angles rounded; frontal area elongated. Outer teeth of protibia larger than in males. Transversal carinae I of meso- and metatibia well-marked; mesotibia with two long and simple spurs. Paraproct distinct.

\section{Remarks}

As observed in some works (e.g., Ricchiardi 2002; Morón \& Vaz-de-Mello 2007; Seidel et al. 2018), the species of Inca can be distinguished from the other members of the tribe Incini mainly by the male with divergent lateral horns with internal face densely setose with long setae and elytra with yellow waxy maculae. In the brachycerous males the outer angles of clypeal horn can be indistinct in some species.

\section{Distribution}

From Tamaulipas in Mexico to Paraguay and northern Argentina.

\section{Key to the species of Inca}

1. Clypeal horn present (male).. 2

- Clypeal horn absent (female)

2. Dorsolateral margin of clypeal horn with a long tooth 3

- Dorsolateral margin of clypeal horn without a long tooth......

3. Inner dorsal carina of clypeal horn abruptly interrupted at apex. Elytral disc with large waxy maculae. Outer distal process of parameres long and acuminate. Brazil (São Paulo, Paraná and Santa Catarina) (Figs 1A-E, P, 4A)

I. axeli sp nov.

- Inner dorsal carina of clypeal horn gradually interrupted at apex. Elytral disc without large waxy maculae. Outer distal process of parameres long and rounded. Brazil (Espírito Santo, Minas Gerais and Rio de Janeiro) (Figs 1F-J, Q, 4B) .... I. neglectus sp. nov.

4. Posterior tooth of protibia short and rounded. Posterior angles of pronotum rounded. Brazil (Rio de Janeiro) (Fig. 1K-O, R).

- Posterior tooth of protibia long and acute or short and rounded. Posterior angles of pronotum acuminate.

5. Clypeal horn with proximal emargination. Posterior tooth of protibia short and rounded.

- Clypeal horn without proximal emargination. Posterior tooth of protibial long and acute 
6. Inner dorsal carina of clypeal horn distinct. Legs without red reflections. Brazil (Minas Gerais, Rio de Janeiro, Paraná, Santa Catarina and Rio Grande do Sul) (Fig. 4H).

.I. besckii Burmeister \& Schaum, 1840

- Inner dorsal carina of clypeal horn indistinct. Legs with red reflections. Argentina, Bolivia, Brazil and Paraguay (Fig. 4G)

I. bonplandi (Gyllenhal, 1817)

7. Medial and lateral area of pronotum and pygidium without yellow longitudinal bands. Brazil, Argentina, Paraguay (Fig. 4F)

- Medial and lateral area of pronotum and pygidium with yellow longitudinal bands (I. clathratus)...8

8. Inner dorsal carina of clypeal horn abruptly interrupted at apex. Trinidad (Fig. 4E).

I. clathratus quesneli Boos \& Ratcliffe, 1985

- Inner dorsal carina of clypeal horns gradually interrupted at apex.

9. Inner dorsal carina convergent to the inner apical angle. Mexico, Guatemala, Belize, Honduras, Nicaragua, Costa Rica, Panama, Colombia and Ecuador (Fig.4C)

I. clathratus sommeri Westwood, 1844

- Inner dorsal carina convergent to the outer apical angle. Colombia, Brazil, Ecuador, Guyana, Suriname, French Guyana, Peru, Bolivia and Argentina (Fig. 4D).

I. clathratus clathratus (Olivier, 1792)

10. Anterior margin of clypeus with a medial tooth

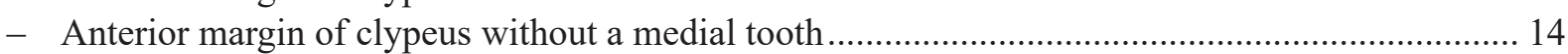

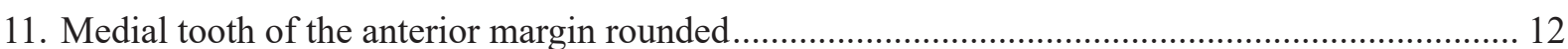

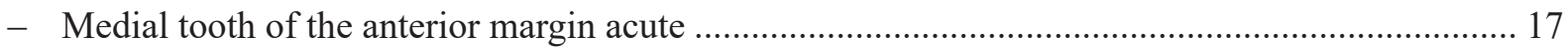

12. Disc of clypeus with a large fovea. Lateral margin of pronotum with deep crenulation. Marks of medial area of elytral epipleuron evident. Brazil (Rio de Janeiro) (Figs 2I-K, O, 3C, F) ....

I. irroratus Chevrolat, 1833

- Clypeus without fovea. Lateral margin of pronotum with shallow crenulation. Marks of medial area of elytral epipleuron indistinct. 13

13. Medial tooth of anterior margin of clypeus evident. Elytral disc with large waxy maculae. Brazil (São Paulo, Paraná and Santa Catarina) (Figs 2A-C, M, 3A, D) ... I. axeli sp nov.

- Medial tooth of anterior margin of clypeus almost indistinct. Elytral disc without large waxy maculae. Brazil (Espírito Santo, Minas Gerais and Rio de Janeiro) (Figs 2E-G, N, 3B, E)

I. neglectus sp. nov.

14. Pronotum and pygidium densely maculate without yellow longitudinal bands. Brazil, Argentina, Paraguay (Fig. 4F) I. pulverulentus (Olivier, 1789)

- Pronotum and pygidium weakly maculate with medial and lateral areas with yellow longitudinal bands (I. clathratus)....

15. Widely distributed in Mexico and Central America and restricted to South America on the east side of the Andes Mountains in Colombia and Ecuador. I. clathratus sommeri Westwood, 1844

- Distributed in South America, on the west side of the Andes Mountains $16^{*}$

16. Restricted to Trinidad

I. clathratus quesneli Boos \& Ratcliffe, 1985

- Distributed in Colombia, Brazil, Ecuador, Guyana, French Guyana, Peru, Bolivia and Argentina I. clathratus clathratus (Olivier, 1792) 
17. Legs without red reflections. Brazil (Minas Gerais, Rio de Janeiro, Paraná, Santa Catarina and Rio Grande do Sul) (Fig. 4H)

- Legs with red reflections. Argentina, Bolivia, Brazil and Paraguay...I. bonplandi (Gyllenhal, 1817)

"Step 16 separates the females of I. clathratus s. str. to I. clathratus quesneli. However, the morphology of these species is not informative for the distinction of these taxa. Beyond geographic distribution the females of I. clathratus quesneli are usually bigger than I. clathratus s. str. and can have bluish black tegument coloration beyond the dark green, black or brownish black coloration of I. clathratus s. str. Further studies are needed to better clarify the taxonomy of these species.

\section{Inca irroratus species group}

\section{Diagnosis}

The species of the irroratus group can be distinguished from other species groups of Inca by: outer dorsal margin of clypeal horns of males with an acute or rounded tooth (this tooth is outwardly directed); distal area of parameres acuminate; clypeus of females with a posteromedian process and disc convex; medial tooth of the anterior margin rounded (see Table 1).

$$
\begin{aligned}
& \text { Inca axeli sp. nov. } \\
& \text { urn:lsid:zoobank.org:act:C559A3D8-DD5D-4B6B-95A1-62276FAE6A79 }
\end{aligned}
$$

Figs 1A-E, P, 2A-D, M, 3A, D, G-N, 4A

\section{Differential diagnosis}

Inca axeli sp. nov. is very similar to I. neglectus sp. nov. in that both species have clypeal horns in males with dorsolateral tooth long and acute (short and rounded in I. irroratus), posterior angles of pronotum acute (rounded in I. irroratus), medial area of elytra with large waxy maculae (absent in I. irroratus), and posterior tooth of protibia long and acute (short and rounded in I. irroratus). Inca axeli sp. nov. has the inner dorsal carina of clypeal horns abruptly interrupted at apex (gradually interrupted in I. neglectus sp. nov. and I. irroratus) and the outer distal process of parameres long and acuminate (long and rounded in I. neglectus sp. nov. and short and rounded in I. irroratus) (see Table 2).

\section{Etymology}

It is a pleasure for the last author to name the species after Axel González Gallardo in gratitude for the last years together and all his support.

\section{Material examined}

Holotype

BRASIL - Santa Catarina - đ̇; SC, Joinville; Dirings coll.; "HOLOTYPE, Inca axeli, Sousa \& Seidel, 2019"; MZSP 22036.

Paratypes ( $13 \hat{\partial} \widehat{\partial}$ and 25 우 $)$

BRAZIL - No detailed localities • 1 ग, 1 क; "Brasilien, Jäger coll., I. Burmeisteri, Brasil, Beske"; SMNS • 1 क; same collection data as for preceding; ZMH 833672 • 1 ö; "Brasil, Inca pulverulentus, Le Moult vend via Reinbek, Eing. Nr. 1, 1957”; ZMH 833671. - Amazonas • 1 \%; "AM; Benjamin

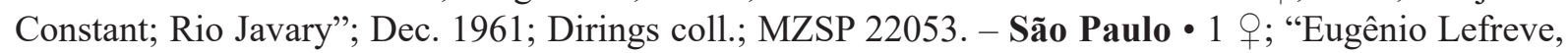
Pindamonhangaba, S.P.”; Mar. 1963; "Exp. Dep. Zoologia, INCA IRRORATUS, CHEVR., det. B.C. Ratcliffe 1983"; MZSP 22020 • 1 đ̊; Est. Bio. Boraceia [Estação Biológica da Boracéia], Salesópolis; 1-4 Feb. 1973; Vanin coll.; "INCA SP NOV., proche de irroratus [handwritten]; det. P. Bleuzen 1992"; MZSP 22007 • 1 \&; São Paulo, (capital); Dirings coll.; Jan. 1960; MZSP 22054 • 1 +; S. Bocaína, Parq. 
Table 1. Comparative table between Inca species groups (bonplandi group =I. besckii, I. bonplandi; clathratus group = I. clathratus clathratus, I. clathratus quesneli, I. clathratus sommeri, I. pulverulentus; irroratus group $=I$. axeli sp. nov., I. neglectus sp. nov., I. irroratus).

\begin{tabular}{lccc}
\hline Character & bonplandi group & clathratus group & irroratus group \\
\hline Dorsolateral tooth of clypeal horns & absent & absent & present \\
\hline Proximal emargination of clypeal horns & present & absent & absent \\
\hline $\begin{array}{l}\text { Clypeal posteromedian process of female } \\
\text { Medial tooth of the anterior margin }\end{array}$ & absent & absent & present \\
\hline Female clypeal disc & acute & absent & rounded \\
\hline Posterior area of female clypeus & concave & concave & convex \\
\hline Waxy maculae on hypomeron punctuation & surface & $\begin{array}{c}\text { with waxy } \\
\text { surface }\end{array}$ & $\begin{array}{c}\text { without waxy } \\
\text { surface }\end{array}$ \\
\hline $\begin{array}{l}\text { Proximal sinuosity of outer face } \\
\text { of male protibia }\end{array}$ & absent & absent & absent \\
\hline Male protibial outer tooth III & spiniform & unciform & absent \\
\hline Distal area of parameres & rounded & rounded & acuminiform \\
\hline
\end{tabular}

criac. Trutas [parque de criação de trutas]; 1800 m a.s.1.; Mar. 1954; "Dalcy, R. Barros; Coll. IRSNB, ex coll. J. ROUCH, I.G.: 32.703”; RBINS. - Paraná • 1 ō, 1 क; Piraquara, Manaciais da Serra; 3 Mar. 2012; CEMT • 1 §ै; Santo Antonio ; 20 Mar. 1993; “Coll. P. BLEUZEN, Coll. IRSNB, ex coll. J. ROUCH, I.G.: 32.703, Photo N. Mal 2015"; RBINS. - Santa Catarina • 1 q; Joinville; Dirings coll.; MZSP 22051 • 1 ô; Timbó; MZSP 22004・ 1 ô;; Timbó; Jun. 1969; Dirings coll.; MZSP 22035 - 1 đ; Timbó; May 1956; Dirings coll.; MZSP 22038 • 1 q; Timbó; Feb. 1960; Dirings coll.; MZSP 22018 • 1 q; Timbó; Mar. 1960; Dirings coll.; MZSP 22019 • 7 q ; Timbó; Mar. 1960; Dirings coll.; MZSP 22041-22047 • 3 웅 Timbó; Jun. 1969; Dirings coll.; MZSP 22048-22050 • 1 ㅇ, 1 ơ; Rio Vermelho; Mar. 1949; Dirings coll.; MZSP 22039-22040 • 1 q; Rio Vermelho; Nov. 1963; Dirings coll.; MZSP 22052 • 1 đ; CORUPA; Feb. 1952; "Anton Maller; coleção CAMPOS SEABRA; Coll. IRSNB, ex coll. J. ROUCH, I.G.: 32.703"; RBINS • 1 O+; CORUPA; "II"; "Anton Maller; coleção CAMPOS SEABRA; Coll. IRSNB, ex coll. J. ROUCH, I.G.: 32.703”; RBINS • 1 đ; Campo Alegre; 23 Feb. 1997; "Coll. IRSNB, ex coll. J. ROUCH, I.G.: 32.703"; RBINS • 1 क; Jaragua do Sul; Feb. 1991; "Coll. Th. PORION; Coll. IRSNB, ex coll. J. ROUCH, I.G.: 32.703, Photo N. Mal 2015”; RBINS • 1 §’; Hansa Humbolt; Mar. 1929; “A. Maller; L. Burgeon, coll.et det., R.I.Sc.N.B.16.117”; RBINS • 1 ô; "Brésil, Sta Catarina", "J.P.MARECHAL; Coll. IRSNB, ex coll. J. ROUCH, I.G.: 32.703"; Coll. Matthias Seidel 2019; MSPC • 1 क; Campo Alegre; 23 Feb. 1997; "Coll. IRSNB, ex coll. J. ROUCH, I.G.: 32.703”; Coll. Matthias Seidel 2019; MSPC.

Paratypes deposited in CEMT, MZSP and UFRPE are labelled with "PARATYPE; Inca axeli; Sousa \& Seidel, 2019" and paratypes deposited in MSPC, RBINS, SMNS and ZMH are labelled with "PARATYPE; Inca axeli sp. nov., M. Seidel \& R. Sousa, 2019".

\section{Description}

Holotype (male)

Body (Fig. 1A-C). Total length including clypeal horns $40 \mathrm{~mm}$; width across humeri $17 \mathrm{~mm}$.

Colour. Reddish brown with dark green heterogeneous spots, dorsal surface with green metallic reflections; legs and meso- and metathorax bright reddish brown (Fig. 1A-C, P). 


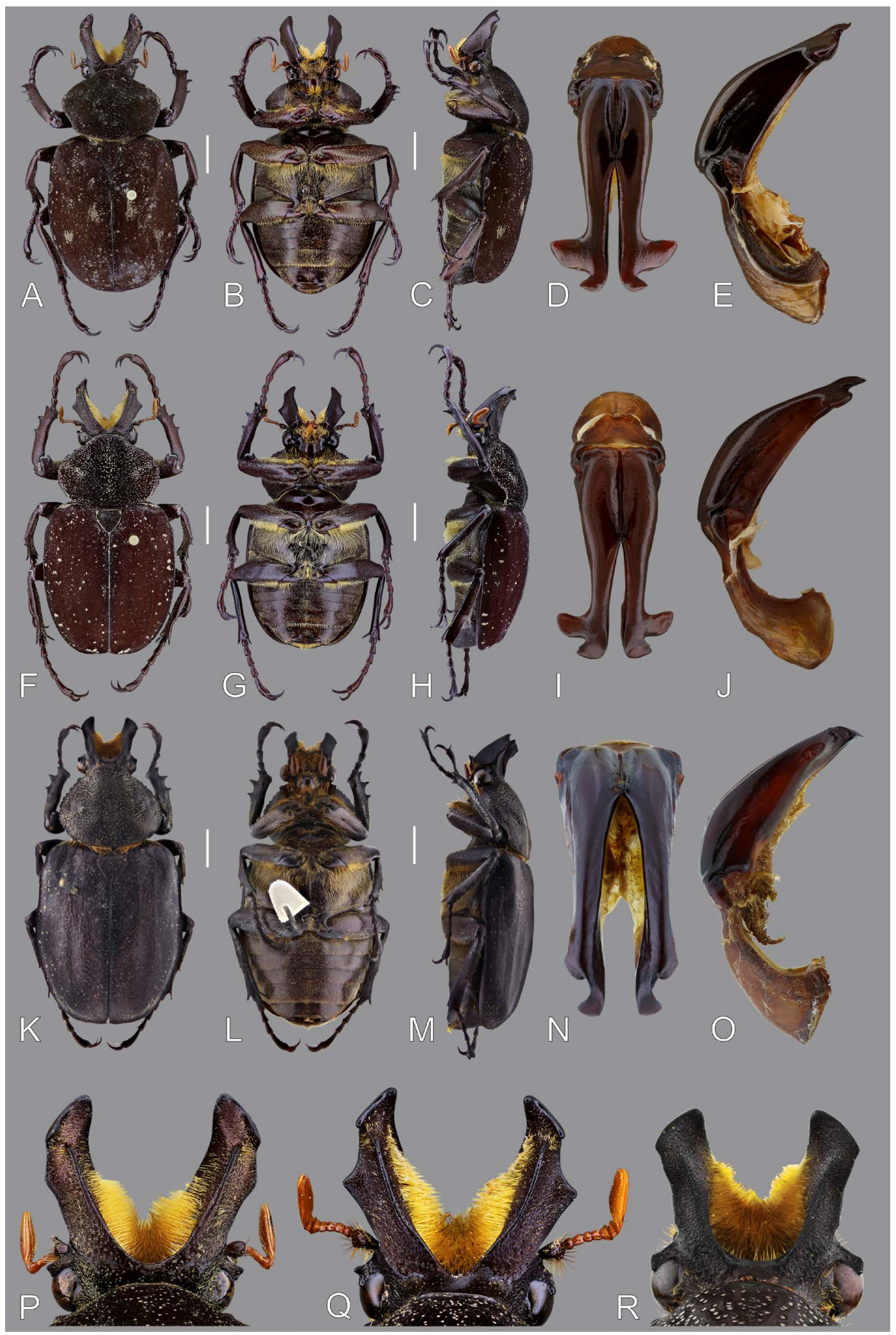

Fig. 1. Males of Inca spp. A-E, P. Inca axeli sp. nov., holotype (MZSP 22036). - F-J, Q. Inca neglectus sp. nov., paratype (MZSP). - K-O, R. Inca irroratus Chevrolat, 1833, neotype (BMNH). A, F, K. Dorsal habitus. B, G, L. Ventral habitus. C, H, M. Lateral habitus. D, I, N. Dorsal view of aedeagus. E, J, O. Lateral view of aedeagus. P-R. Dorsal view of head. Scale bars $=5 \mathrm{~mm}$. 
HEAD. Surface of frons with dark green and dark reddish-brown waxy secretion; clypeal horns with anterior area of inner dorsal carina truncate, abruptly interrupted and not reaching distal angles; dorsolateral tooth long and acute (Fig. 1P).

THORAX. Lateral margin of pronotum strongly sinuous; lateromedial area with elongated and irregular fovea; longitudinal groove shallow; posterior angles acute (Fig. 1A-C). Anterior prosternal process acute, projected and densely setose in median area. Anterolateral area of scutellar shield punctate. Elytra with yellowish grey heterogeneous waxy maculae covering all surface and two large maculae in medial area (Fig. 1A).

LEGS. Posterior tooth of protibia long and acute (Fig. 3A). Mesempodium with 2 setae.

AbDomen. Fovea of sternite VII strongly marked. Disc of pygidium densely punctate, lateral area with well-defined punctures.

Terminalia. Aedeagus: outer distal process of parameres long and acuminate (Fig. 1D-E).

Morphological variations (males). Body length 30-45 mm, width 13-17 mm. Head: clypeal horns with or without green metallic reflection; brachycerous males with clypeal horns with dorsolateral tooth small and inner dorsal carina abruptly or gradually interrupted at apex. Thorax with anterior prosternal process rounded and small. Density of waxy maculae of elytra variable, maculae yellowish grey or golden yellow; the two large maculae in median area variable in shape and size.

LEGS. Mesempodium with 2-4 setae.

\section{Female}

Body (Fig. 2A-C). Length 32-42 mm; width across humeri 15-18 mm. Maculae of medial area of elytra usually larger than in males.

\section{Type locality}

Joinville, Santa Catarina State, Brazil.

\section{Distribution}

Brazil: São Paulo (Pindamonhangaba, Salesópolis, São Paulo) Paraná (Piraquara), Santa Catarina (Campo Alegre, Joinville, Corupá, Jaraguá do Sul, Timbó, Florianópolis, Bocaina do Sul) (Fig. 5). The female paratype from Benjamin Constant (Amazonas) is probably labelled incorrectly.

\section{Biology}

Two larvae of I. axeli sp. nov. were collected inside the base of a dead bromeliad (possibly Vriesea sp. or Aechmea sp.) in a fallen tree at Mananciais da Serra, Piraquara, Paraná State, Brazil (pers. com. Paschoal Grossi). 


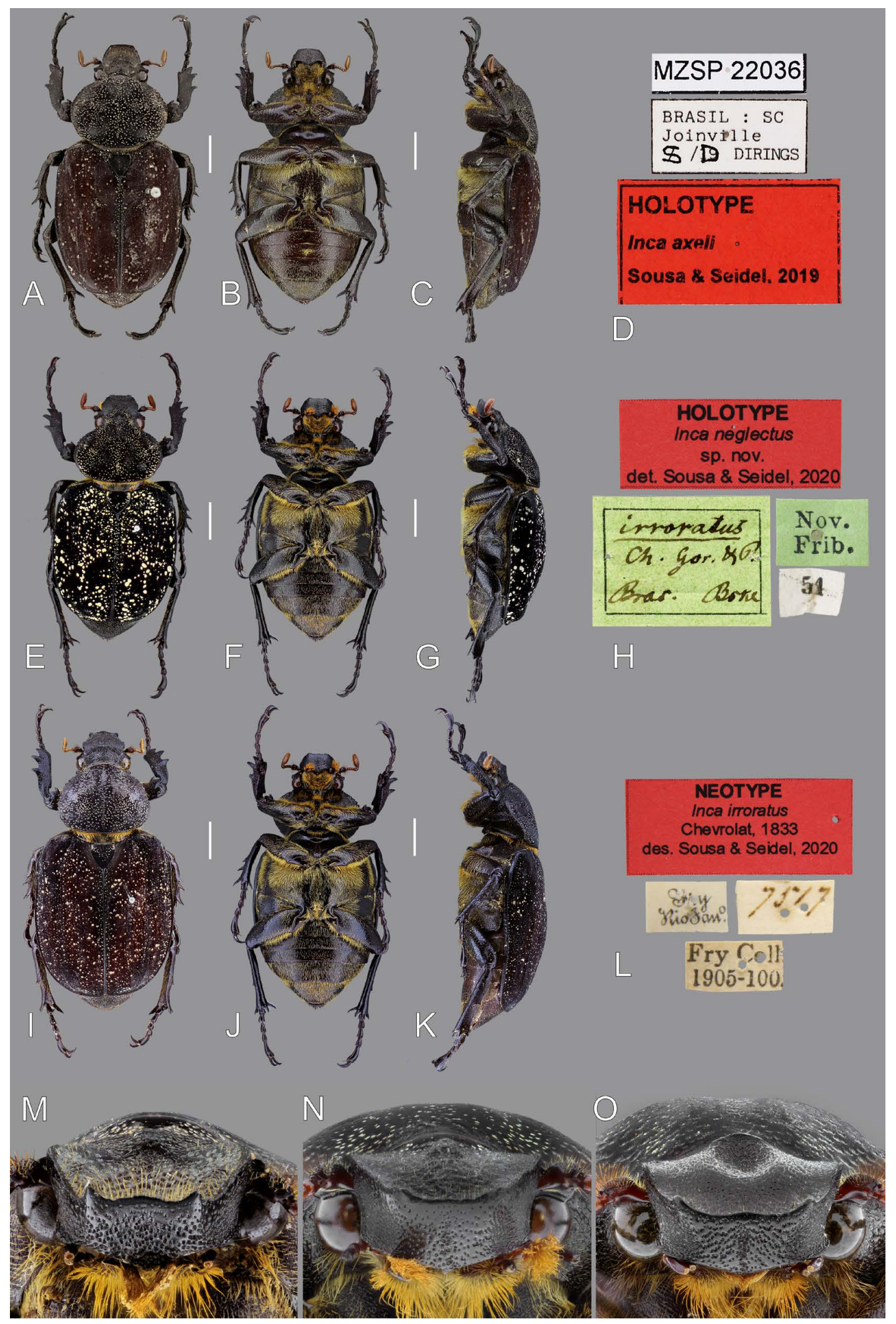

Fig. 2. Females of Inca spp. and type labels. A-D, M. Inca axeli sp. nov. - E-H, N. Inca neglectus sp. nov. - I-L, O. Inca irroratus Chevrolat, 1833. A, E, I. Dorsal habitus. B, F, J. Ventral habitus. C, G, K. Lateral habitus. D, H, L. Type labels. M-O. Frontal view of head. Scale bars $=5 \mathrm{~mm}$. 


\section{Inca neglectus $\mathrm{sp}$. nov. urn:1sid:zoobank.org:act:21C602CA-DB1D-41A4-8BCA-5A2DC0E227FD}

Figs $1 \mathrm{~F}-\mathrm{J}, \mathrm{Q}, 2 \mathrm{E}-\mathrm{H}, \mathrm{N}, 3 \mathrm{~B}, \mathrm{E}, 4 \mathrm{~B}$

\section{Differential diagnosis}

Inca neglectus sp. nov. is very similar to $I$. axeli sp. nov. in that both species have clypeal horns in males with dorsolateral tooth long and acute (short and rounded in I. irroratus), posterior angles of pronotum acute (rounded in I. irroratus), medial area of elytra with large waxy maculae (absent in I. irroratus), and posterior tooth of protibia long and acute (short and rounded in I. irroratus). Inca neglectus sp. nov. has the inner dorsal carina of clypeal horns gradually interrupted (abruptly interrupted at apex in I. axeli sp. nov.) and the outer distal process of parameres long and rounded (long and acuminate in I. axeli sp. nov. and short and rounded in I. irroratus) (see Table 2).

\section{Etymology}

The species epithet comes from the Latin word 'neglectus' referring to the species being neglected taxonomically since Burmeister first described it, but did not name it, in 1847.

\section{Material examined}

\section{Holotype}

BRAZIL - Rio de Janeiro • 1 đ’; "Bras. [Brasil], Nov. Frib. [Nova Friburgo], Bske [Bescke] leg., 54, irroratus Ch. Gor. \& P, HOLOTYPE, Inca neglectus, sp. nov., det. Sousa \& Seidel 2020”; MLUH.

$$
\text { Paratypes ( } 6 \hat{\partial} \widehat{\partial} \text { and } 4 \text { 웅) }
$$

BRAZIL - Espirito Santo - 1 đ; "Brasil, Espirito Santo, Ex col. Visc. Bonvouloir, Inca irroratus Chevr. (?), Burm., 1847 (not 1842), G.J.Arrow det., Brit. Mus. 1946-356”; BMNH. - Minas Gerais - 1 §;; Ouro Preto; 27 Dec. 1998; F. Ohaus leg.; MZSP. - Rio de Janeiro • 1 q ; "Bras. [Brasil], Nov. Frib. [Nova Friburgo], Bske [Bescke] leg., irroratus Ch. Gor. \& P.”; MLUH • 1 o, 1 क; "Bras. [Brasil], Bske [Bescke] leg., irroratus Ch. Gor. \& P"; MLUH • 1 ô; Nova Friburgo, Garrafão, Cascatinha, 23 Mar. 2003; UFRPE • 1 क ; same locality as for preceding; 6 Apr. 2002; UFRPE • 1 ; ; same locality as for preceding; Mar. 1999; R. Vassalo leg., "Coleção F. \& P. Grossi”; UFRPE • 1 đ̃; same locality as for preceding; 27 Mar. 2004; R. Vassalo leg.; UFRPE • 1 ○ૈ; Petropolis; "21.7.947 [21 Jul. 1947], Luiz P. Leite, Coll. IRSNB, Inca besckei Schaum; ex coll J. ROUCH, I.G.: 32.703”; RBINS.

Paratypes are labelled with "PARATYPE; Inca neglectus; sp. nov.; det. Sousa \& Seidel, 2020".

\section{Description}

\section{Holotype (male)}

Body (Fig. 1I-H [=images of almost identical paratype]). Total length including clypeal horns $42.0 \mathrm{~mm}$; width across humeri $17.0 \mathrm{~mm}$.

CoLour. Reddish brown with dark green heterogeneous spots, dorsal surface with weak green and orange metallic reflections; legs and meso- and metathorax with reddish brown bright colour (Fig. 1FH, Q).

HEAD. Surface of frons with dark green and dark reddish-brown waxy secretion; clypeal horns with anterior area of inner dorsal carina gradually interrupted at apex; dorsolateral tooth long and acute (Fig. 1Q).

THORAX. Lateral margin of pronotum strongly sinuous; lateromedial area with elongated and irregular fovea; longitudinal groove well marked; posterior angles acute (Fig. 1I-H). Anterior prosternal process 
Table 2. Comparative table for the species of the irroratus group.

\begin{tabular}{lccc}
\hline & I. axeli sp. nov. & I. neglectus sp. nov. & I. irroratus \\
\hline Large fovea of female clypeal disc & absent & absent & present \\
\hline $\begin{array}{l}\text { Medial tooth of anterior margin } \\
\text { of clypeus of females }\end{array}$ & evident & almost indistinct & evident \\
\hline $\begin{array}{l}\text { Distal interruption of inner dorsal } \\
\text { carina of clypeal horns }\end{array}$ & abrupt & gradual & gradual \\
\hline Dorsolateral tooth of clypeal horns & long and acute & long and acute & short and rounded \\
\hline Posterior angles of pronotum of males & acute & acute & rounded \\
\hline $\begin{array}{l}\text { Shape of lateral margin of pronotum } \\
\text { of pronulation of lateral margin }\end{array}$ & strongly sinuous & strongly sinuous & slightly sinuous \\
\hline Posterior tooth of protibia & shallow & shallow & deep \\
\hline $\begin{array}{l}\text { Marks of medial area } \\
\text { of elytral epipleuron }\end{array}$ & long and acute & long and acute & short and rounded \\
\hline Large waxy maculae of elytral disc & indistinct & indistinct & evident \\
\hline Fovea of sternite VII & strongly marked & strongly marked & slightly marked \\
\hline $\begin{array}{l}\text { Outer distal process of parameres } \\
\text { long and }\end{array}$ & long and rounded & short and rounded \\
\hline
\end{tabular}

acute, projected and densely setose in the median area; can be acute or rounded and little or strongly projected. Anterolateral area of scutellar plate punctate. Elytra little maculated with light yellow waxy maculae covering all surface (Fig. 1F).

LEGS. Posterior tooth of protibia long and acute (Fig. 3B). Mesempodium with 2 setae.

AвDOMEN. Fovea of sternite VII strongly marked. Disc of pygidium densely punctate, lateral area with well-defined punctures.

Terminalia. Aedeagus: outer distal process of parameres long and rounded (Fig. 1I-J).

MORPHOLOGICAL VARIATIONS (males). Body length 33-42 mm, width 14-17 mm. Head. In brachycerous specimens the dorsolateral tooth can be rounded and reduced in size.

\section{Female}

Body (Fig. 2E-G). Length 40-42 mm; width across humeri 16-18 mm. Colour of waxy secretion of elytra surface varies from reddish brown to dark reddish brown with waxy maculae that can vary from light yellow to gold yellow colour.

\section{Type locality}

Nova Friburgo, Rio de Janeiro State, Brazil.

\section{Distribution}

Brazil: Espírito Santo, Minas Gerais (Ouro Preto) and Rio de Janeiro (Nova Friburgo) states (Fig. 5).

\section{Remarks}

Burmeister (1847) described and diagnosed this species under I. irroratus. After careful examination of morphological evidence we conclude that the real I. irroratus is actually what Burmeister identified 


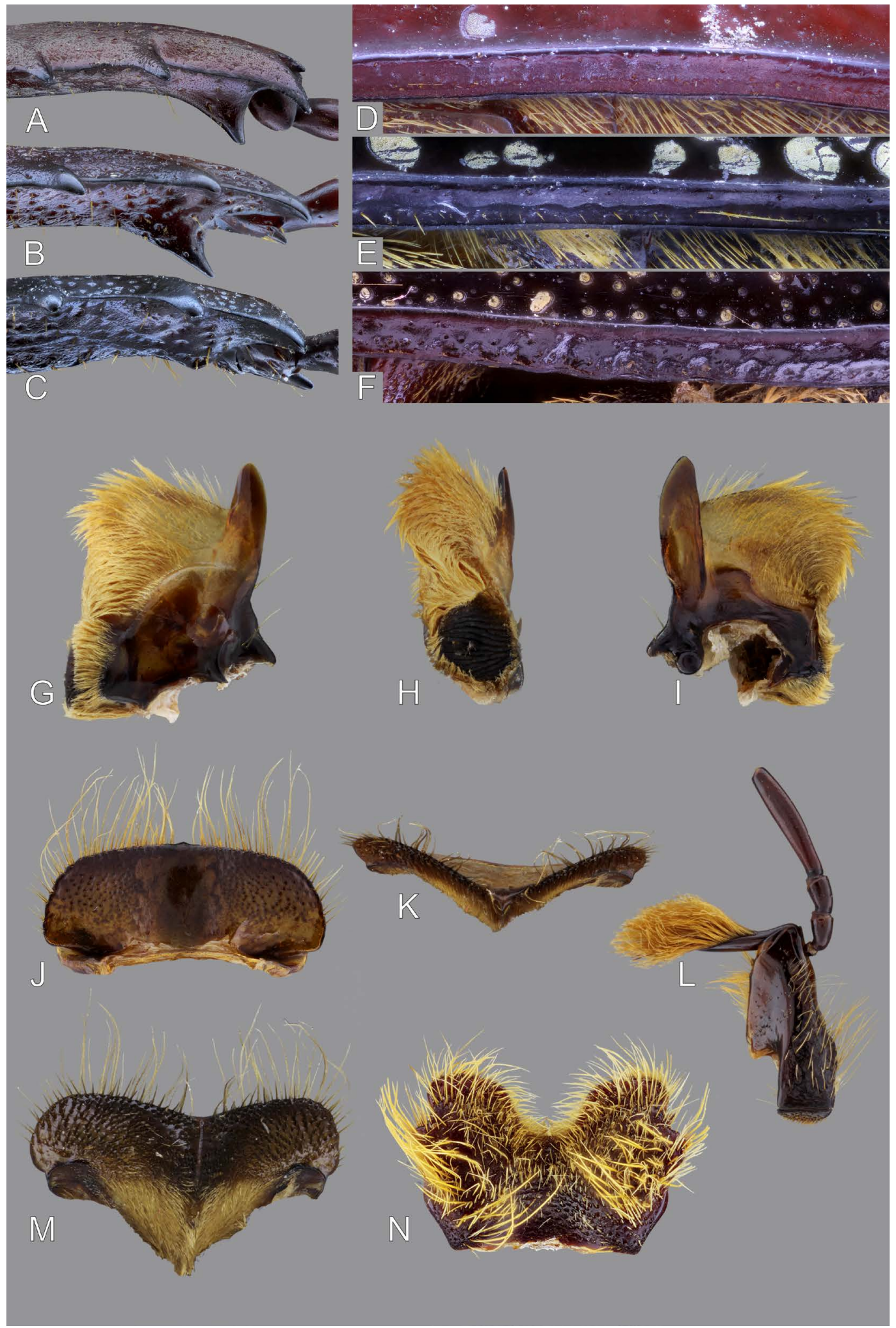

Fig. 3. Morphological details of Inca spp. A, D, G-N. I. axeli sp. nov. (A, D: , G-N ð). - B, E. I. neglectus sp. nov. - C, F. I. irroratus Chevrolat, 1833. A-C. Protibia, lateral view. D-F. Details of elytral epipleuron. G-N. Mouthparts. G-I. Right mandibles (dorsal, inner and ventral view). J-K. Labrum (dorsal and frontal view). L. Right maxilla (dorsal view). M. Epipharynx. N. Labium. 

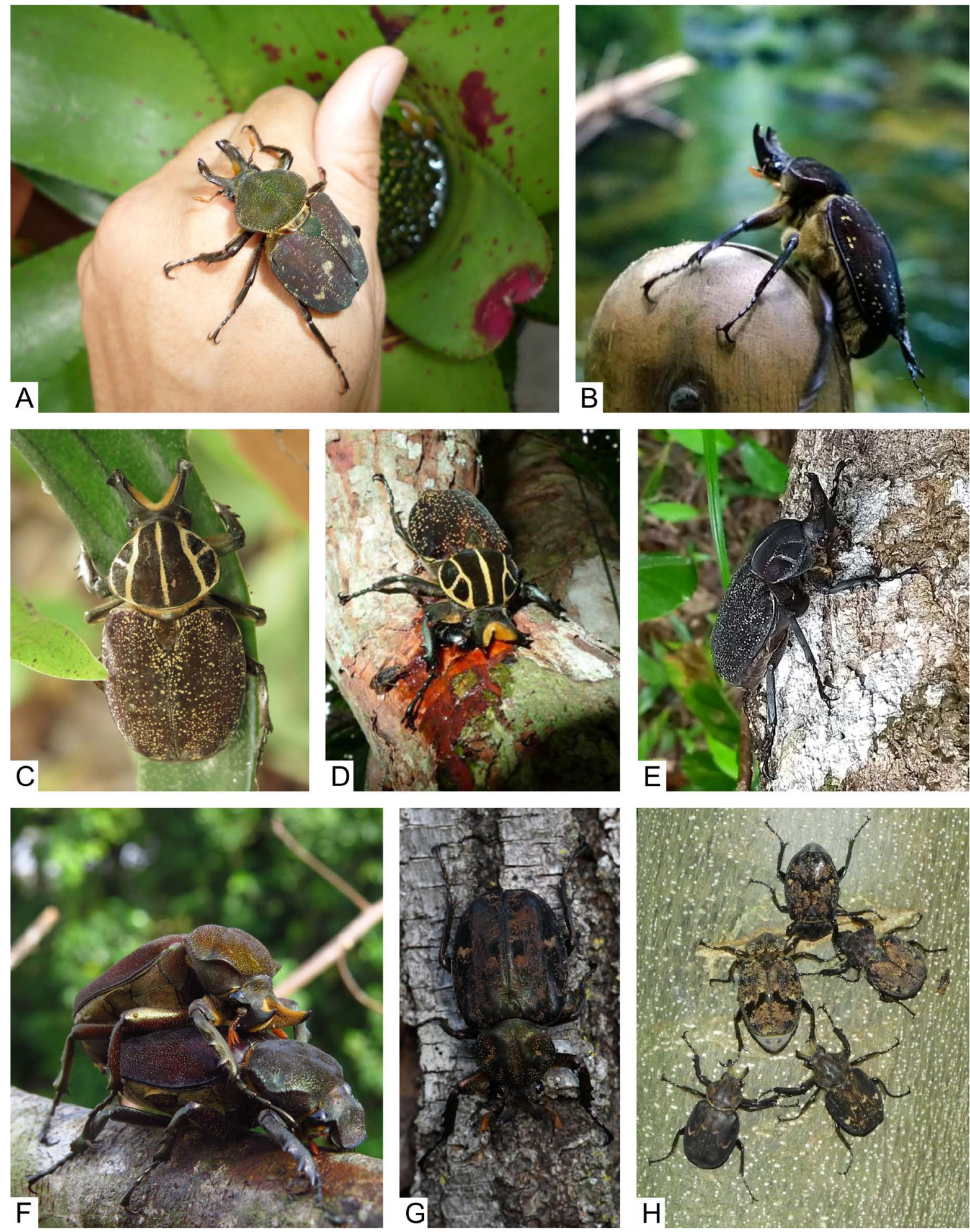

Fig. 4. Images of live Inca spp. A. Inca axeli sp. nov. (photo by R. Barros and R. Koike). B. Inca neglectus sp. nov. (photo by N. Marchito). C. Inca clathratus sommeri Westwood, 1844 (photo by A. González Gallina). D. Inca clathratus clathratus (Olivier, 1792) (photo by R. Barros and R. Koike). E. Inca clathratus quesneli Boos \& Ratcliffe, 1985 (photo by M. Hulme). F. Inca pulverulentus (Olivier, 1789) mating (photo by R. Barros and R. Koike). G. Inca bonplandi (Gyllenhal, 1817) (photo by J. Touroult). H. Inca besckii Burmeister \& Schaum, 1840 feeding on tree sap (photo by N. Wisnik). 
as his new species $I$. burmeisteri, leaving this species unnamed. The specimens listed in 'additional material' under I. burmeisteri in Seidel et al. (2018) belong to I. neglectus sp. nov.

Inca irroratus Chevrolat, 1833

Figs $1 \mathrm{~K}-\mathrm{O}, \mathrm{R}, 2 \mathrm{I}-\mathrm{L}, \mathrm{O}, 3 \mathrm{C}, \mathrm{F}, 5$

Ynca irrorata Chevrolat, 1833: unpaginated.

Inca irroratus Burmeister \& Schaum, 1840: 380.

Inca burmeisteri Burmeister, 1847: 568. Syn. nov.

\section{Differential diagnosis}

Inca irroratus can be distinguished from the other two species of the group by: females with clypeus bearing a medial rounded fovea (fovea absent in I. axeli sp. nov. and I. neglectus sp. nov.); medial tooth well developed (almost indistinct in I. neglectus sp. nov.); clypeal horns in males with dorsolateral tooth short and rounded (long and acute in I. axeli sp. nov. and I. irroratus); pronotum with posterior angles rounded (acute in $I$. axeli sp. nov. and I. neglectus sp. nov.) and lateral margin slightly sinuous and deeply crenulated (strongly sinuous and shallowly crenulated in I. axeli sp. nov. and I. neglectus sp. nov.); posterior tooth of protibia short and rounded (long and acute in I. axeli sp. nov. and I. neglectus sp. nov.); epipleuron with irregular and rounded marks on median area (indistinct marks in $I$. axeli sp. nov. and I. neglectus sp. nov.); outer distal process of parameres short and slightly rounded (long and acuminated in I. axeli sp. nov.; long and rounded in I. neglectus sp. nov.) (see Table 2).

\section{Material examined}

Neotype of Inca irroratus (here designated)

BRAZIL - Rio de Janeiro • 1 §̋; “Rio. Jan. [Rio de Janeiro], Fry; 7517, Fry Coll. 1905-100.”; BMNH.

Lectotype of Inca burmeisteri (here designated)

BRAZIL - Rio de Janeiro • 1 ડ̄; "Bras. [Brasil], Bske [Bescke] leg., Burmeisteri*, Besck, LECTOTYPE, Inca burmeisteri, Burmeister, 1847, des. Sousa \& Seidel 2020"; MLUH.

\section{Paralectotypes of Inca burmeisteri}

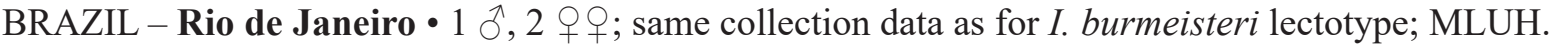

\section{Additional material}

BRAZIL - Rio de Janeiro • 1 q; Nova Friburgo, Mury; 1200 m a.s.l.; Apr. 1999; R. Rajs coll., "Coleção E \& P. Grossi"; UFRPE • 1 o;; "Rio. Jan. [Rio de Janeiro], Fry, Ynca burmeisteri Burm, irroratus (Oliv) Burm; Brasilia, Fry Coll. 1905-100”; BMNH.

\section{Type locality}

Rio de Janeiro, Brazil.

\section{Redescription}

Male

Body (Fig. 1K-M). Total length including clypeal horns 43-47 mm (neotype: $44 \mathrm{~mm}$ ); width across humeri 18-19 $\mathrm{mm}$ (neotype: $18 \mathrm{~mm}$ ).

CoLour. Reddish brown; dorsal surface with metallic reflections; legs and meso- and metathorax with reddish brown bright colour (Fig. 1K-M, R). 
HEAD. Surface of frons with reddish brown waxy secretion; clypeal horns with inner dorsal carina weak, anterior area gradually interrupted at apex; dorsolateral tooth short and rounded (Fig. 1R).

THORAX. Lateral margin of pronotum slightly sinuous and deeply crenulated; lateromedial area with grooved fovea; longitudinal groove shallow; posterior angles rounded (Fig. 1K-M); anterior prosternal process evenly rounded, projected and densely setose in median area. Scutellar shield punctate in anterolateral area. Elytra with light yellow waxy maculae covering all surface; epipleuron with irregular and rounded marks on median area (Fig. 3F).

LEGs. Posterior tooth of protibia short and rounded (Fig. 3C). Mesempodium with 2 setae.

AвDomen. Fovea of sternite VII slightly marked. Disc of pygidium densely punctate, lateral area with well-defined punctures.

TerminAliA. Aedeagus: outer distal process of parameres short and slightly rounded (Fig. 1N-O).

\section{Female}

Body (Fig. 2I-K). Length 44.0-48.5 mm; width across humeri 18.0-19.5 mm. Disc of clypeus with large and rounded fovea below process of posteromedian area (Fig. 2O).

\section{Distribution}

Brazil: Rio de Janeiro State (Nova Friburgo) (Fig. 5).

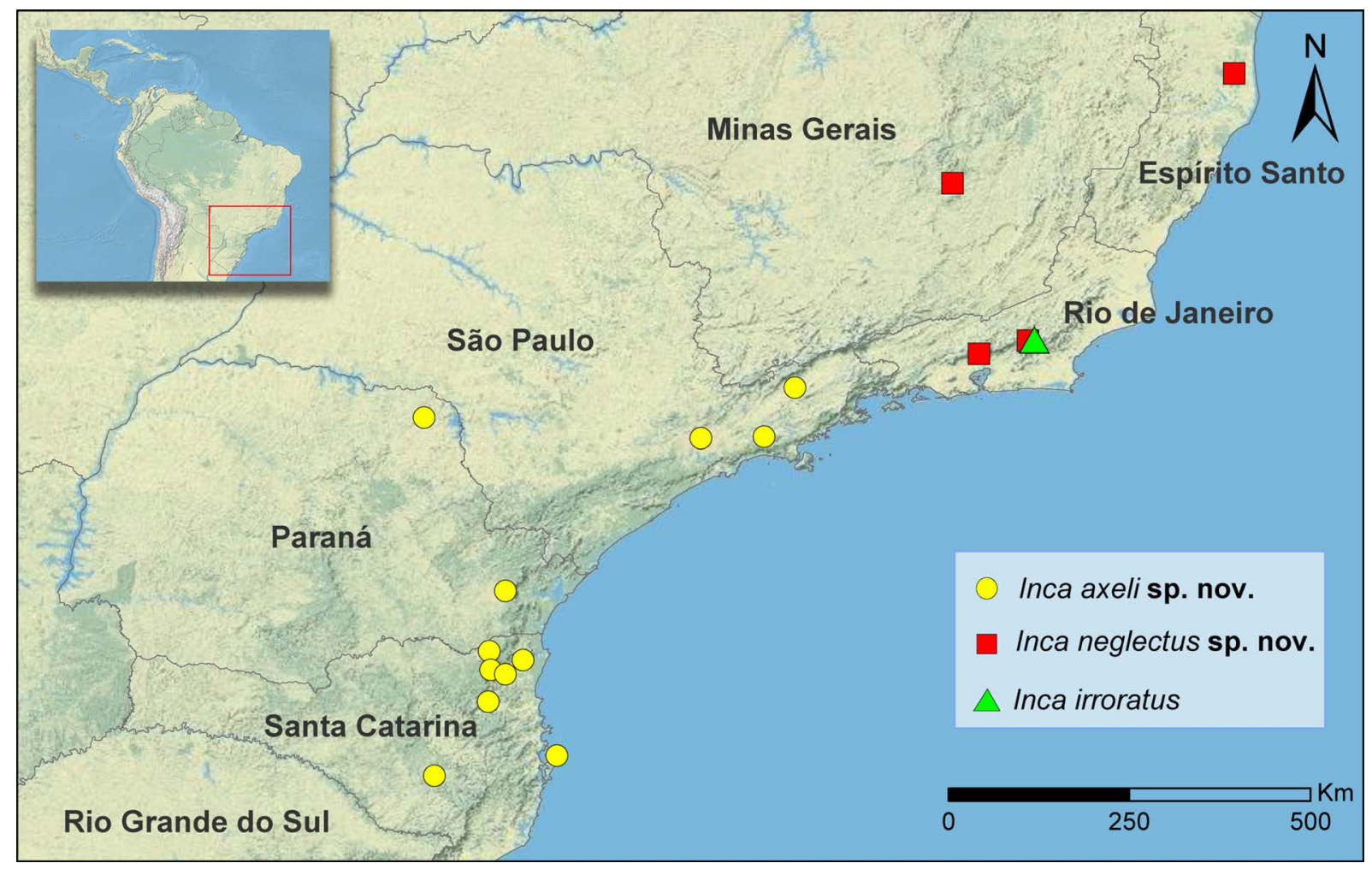

Fig. 5. Distribution map of species of the Inca irroratus group. 


\section{Remarks}

The holotype of I. irroratus cannot be found in the Muséum national d'histoire naturelle (Paris, France) or in the Natural History Museum (BMNH, London, United Kingdom) and we therefore consider it lost. The description by Chevrolat is rather general and does not allow to precisely identify the species. According to Chevrolat, the species is "bearing a very short median horn preceded by the transverse carina", a combination of characters none of the two species in question possess. Females exhibit an elevated carina on the head only in one species (Fig. 2O), whereas the other (Fig. 2N) only possesses a cone-shaped tubercle. None of the species have a horn. Additionally, based on the illustration of the type of I. irroratus by Gory \& Percheron (1833), which lacks carina and horn, the female has a strongly crenulated pronotal margin and a medial tooth in the clypeal margin. To fix the identity of I. irroratus, we designate a male neotype (conspecific with females possessing the aforementioned characters) from BMNH (Fig. 1K-O, R) from the type locality (Rio de Janeiro).

Not knowing the exact number of syntypes and their depositories and to guarantee nomenclatural stability, we designate a male lectotype for I. burmeisteri from the syntype series deposited in MLUH. The lectotype of I. burmeisteri is conspecific with I. irroratus, and therefore I. burmeisteri becomes a junior synonym. For I. irroratus sensu Burmeister (1847), see the description of I. neglectus sp. nov.

\section{Discussion}

For the first time, the type material of the irroratus group was reviewed and species identities could be established, leading to the synonymy of I. burmeisteri with I. irroratus. The designation of a neotype for I. irroratus and the lectotype designation for I. burmeisteri stabilise the taxonomy and make them identifiable for the first time for over 170 years. Two additional distinct species, I. axeli sp. nov. and I. neglectus sp. nov. which were usually identified as I. irroratus or I. burmeisteri in entomological collections, are described.

Inca axeli sp. nov. has the widest distribution with respect to the other two species of the group, and specimens are easily found in museum collections. By contrast, I. neglectus sp. nov. and I. irroratus are more restricted in distribution and specimens are scarce in collections. Inca irroratus is only known from Rio de Janeiro where it co-occurs with I. neglectus sp. nov. Inca neglectus sp. nov. has the northernmost distribution of the group and is found in Espírito Santo and Minas Gerais as well. All species seem to be associated with Brazil's Atlantic Forest ecosystem (Mata Atlântica). All species of Inca have more affinity with humid forests such as the Atlantic Forest and Amazon Forest. Between these two biomes there is an extensive corridor of open and dry vegetation called "the diagonal of open formations" or "dry diagonal" formed by the biomes of the Caatinga, Cerrado and Chaco (Vanzolini 1963; Fernandes et al. 2002; Carvalho \& Almeida 2011). There are few records of species of Inca in dryer biomes as the Cerrado and Caatinga. Moreover, the ongoing deforestation of humid biomes as Atlantic Forest makes these species highly vulnerable to extinction, which may also explain the difficulty of finding species in the northern coastal region.

The difficulty in finding material of these species may have contributed to the abovementioned identity confusion. The present study contributes to a better understanding of the morphology of the irroratus species group, but our knowledge on the biology of these species remains sparse. Studies on the morphology of immature stages and data on the behaviour of adults can help to increase the knowledge about these beetles and provide important information for the taxonomy and phylogeny of Incini.

\section{Acknowledgements}

RS thanks Coordenação de Aperfeiçoamento de Pessoal de Nível Superior (proc.: CAPES código financeiro 001) for financial support. We thank all curators listed under Material and methods for allowing 
access to the material under their care. Thanks to Joachim Händel (ZNS, Halle (Saale), Germany) for providing us with label images of the Burmeister collection. Furthermore, we are grateful to Alberto González Gallina (Red de Ambiente y Sustentabilidad, INECOL, Coatepec, México), Rafael Barros (Universidade Estadual de Londrina, Paraná, Brazil), Ricardo Koike (São Paulo, Brazil), Neder Marchito (Nova Friburgo, Rio de Janeiro, Brazil), Julien Touroult (Muséum national d'Histoire naturelle, Paris, France), Mark Hulme (St Augustine, Trinidad and Tobago) and Nelson Wisnik (Campinas, São Paulo, Brazil) for allowing us to publish their live images of species of Inca.

\section{References}

Bates H.W. 1889. [Trichiidae]. In: Godman F.D. \& Salvin O. (eds) Biologia Centrali-Americana. Insecta. Coleoptera. Vol. II. Part 2. Pectinicornia and Lamellicornia: 377-384. Taylor \& Francis, London.

Beutel R.G. \& Lawrence J.F. 2005. Capítulo 4. Coleoptera, morphology. In: Kükenthal W. (founder), Beiner M., Fischer M., Helmecke J.-G., Starck D. \& Wermuth H. (eds) Handbook of Zoology. A Natural History of the Phyla of the Animal Kingdom Volume IV Arthropoda: Insecta Part 38. Coleoptera, Beetles. Volume 1: Morphology and Systematics (Archostemata, Adephaga, Polyphaga partim): 23-27. Walter de Gruyter, Berlin.

Boos J. \& Ratcliffe B.C. 1985. A new subspecies of Inca clathrata from Trinidad, West Indies, and range extensions for Inca clathrata. The Coleopterists Bulletin 39: 381-389.

Bouchard P., Bousquet Y., Davies A.E., Alonso-Zarazaga M.A., Lawrence J.F., Lyal C.H.C., Newton A.F., Reid C.A.M., Schmitt M., Slipinski S.A. \& Smith A.B.T. 2011. Family-group names in Coleoptera (Insecta). ZooKeys, 88: 1-972. [Family Scarabaeidae Latreille, 1802: 40-45].

Burmeister H. 1842. Handbuch der Entomologie, volume 3. T.C.F. Enslin, Berlin.

Burmeister H. 1847. Handbuch der Entomologie, volume 5. Coleoptera Lamellicornia Xylophila et Pectinicornia. T.C.F. Enslin, Berlin.

Burmeister H. \& Schaum H. 1840. Kritische Revision der Lamellicornia melitophila. Erstes Stück (Trichiadae). Zeitschrift für die Entomologie 2: 353-420.

Carvalho C.J.B. \& Almeida E.A.B. 2011. Biogeografia da América do Sul: padrões \& processos. Roca, São Paulo.

Chevrolat A. 1833. Description d'espèces nouvelles. Revue Entomologique - Coléoptères 10: unpaginated. Available from https://www.biodiversitylibrary.org/item/44561\#page/349/mode/1up [accessed 6 Apr. 2021].

Costa C., Vanin S.A. \& Casari S.A. 1988. Larvas de Coleoptera do Brasil. Museu de Zoologia da Universidade de São Paulo, São Paulo.

Di Iorio O. 2013. A review of the Cetoniinae (Coleoptera: Scarabaeidae) from Argentina and adjacent countries: systematics and geographic distributions. Zootaxa 3668: 1-87. https://doi.org/10.11646/zootaxa.3668.1.1

Esri 2016. ArcMap. Ver. 10.5. Environmental Systems Research Institute, Inc. Available from https://desktop.arcgis.com/en/arcmap/ [accessed 6 Apr. 2021].

Fernandes G.W., Varela O., Bucher E.H., Chani J.M., Echevarria A.L., EspíritoSanto M.M., Lima J., Negreiros D. \& Toledo C.S. 2002. Gall-forming insects on woody and herbaceous plant species of the semiarid chaco forest, Argentina. Lundiana 3: 61-66.

Gory H. \& Percheron A. 1833. Monographie des Cétoines et genres voisins, formant, dans les familles naturelles de Latreille, la division des Scarabées mélitophiles. J.-B. Baillière, Paris. 
Howden H.F. 1968. A review of the Trichiinae of North and Central America (Coleoptera: Scarabaeidae). The Memoirs of the Entomological Society of Canada 100 (S54): 5-77.

Krikken J. 1984. A new key to the suprageneric taxa in the beetle family Cetoniidae, with annotated lists of the known genera. Zoologische Verhandelingen 210: 1-75.

Lawrence J.F., Beutel R.G., Leschen R.A.B. \& Ślipiński A. 2010. Capítulo 2. Glossary of morphological terms. In: Kükenthal W. (founder), Beiner M., Fischer M., Helmecke J.-G., Starck D. \& Wermuth H. (eds) Handbook of Zoology. A Natural History of the Phyla of the Animal Kingdom Volume IV Arthropoda: Part 39. Coleoptera, Beetles. Volume 2: Morphology and Systematics (Elateroidea, Bostrichiformia, Cucujiformia partim): 9-20. Walter de Gruyter, Berlin.

Lepeletier A.L.M. \& Serville J.G.A. 1828. Entomologie, ou histoire naturelle des crustacés, des arachnides et des insectes. Encyclopédie méthodique, Histoire naturelle 10: 345-833.

Micó E., Morón M.A., Šípek P. \& Galante E. 2008. Larval morphology enhances phylogenetic reconstruction in Cetoniidae (Coleoptera: Scarabaeoidea) and allows the interpretation of the evolution of larval feeding habits. Systematic Entomology 33 (1): 128-144. https://doi.org/10.1111/j.1365-3113.2007.00399.x

Morón M.A. 1983. Los estados inmaduros de Inca clathrata sommeri Westwood (Coleoptera, Melolonthidae, Trichiinae); con observaciones sobre el crecimiento alometrico del imago. Folia Entomologica Mexicana 56: 31-51.

Morón M.A. 1995. Larva and pupa of Archedinus relictus Moron and Krikken (Coleoptera: Melolonthidae, Trichiinae, Incaini). Pan-Pacific Entomologist 71: 237-244.

Morón M.A. \& Vaz-de-Mello F.Z. 2007. A new species of Archedinus (Coleoptera: Scarabaeoidea: Trichiinae) from Oaxaca, México. The Pan-Pacific Entomologist 83: 110-119.

Ohaus F. 1900. Bericht über eine entomologische Reise nach Centralbrasilien. Stettiner Entomologische Zeitung 61: 164-191, 193-274.

Ricchiardi E. 2002. Notes on the genus Coelocratus Burmeister, 1842 (Coleoptera: Scarabaeidae). Cetoniimania 2 (1): 3-7.

Schenkling S. 1921. Pars 72: Scarabaeidae: Cetoniinae. In: Schenkling S. (ed.) Coleopterorum Catalogus. Volumen XXI. Scarabaeidae III: 1-431. W. Junk, Berlin.

Schenkling S. 1922. Pars 75: Scarabaeidae: Trichiinae, Valginae. In: Schenkling S. (ed.) Coleopterorum Catalogus. Volumen XXI. Scarabaeidae III: 1-58. W. Junk, Berlin.

Seidel M., Arriaga-Varela E. \& Sousa R. 2018. Catalogue of the Incini with the description of the first Archedinus from Honduras (Coleoptera: Scarabaeidae: Cetoniinae). Acta Entomologica Musei Nationalis Pragae 58 (2): 389-405.

Š́pek P. \& Král D. 2012. Immature stages of the rose chafers (Coleoptera: Scarabaeidae: Cetoniinae): a historical overview. Zootaxa 3323: 1-26. https://doi.org/10.11646/zootaxa.3323.1.1

Šípek P., Gill B.D. \& Grebennikov V.V. 2009. Afromontane Coelocorynus (Coleoptera: Scarabaeidae: Cetoniinae): Larval descriptions, biological notes and phylogenetic placement. European Journal of Entomology 106: 95-106. https://doi.org/10.14411/eje.2009.014

Śípek P., Ricchiardi E. \& Perissinotto R. 2012. Immature stages and ecology of two species of the South African genus Stripsipher Gory \& Percheron, 1833 (Coleoptera: Scarabaeidae: Cetoniinae: Trichiini). Zookeys 180: 19-40. https://doi.org/10.3897/zookeys.180.2315

Śípek P., Fabrizi S., Eberle J. \& Ahrens D. 2016. A molecular phylogeny of rose chafers (Coleoptera: Scarabaeidae: Cetoniinae) reveals a complex and concerted morphological 
evolution related to their flight mode. Molecular Phylogenetics and Evolution 101: 163-175. https://doi.org/10.1016/j.ympev.2016.05.012

Sousa R., Fuhrmann J., Kouklík O. \& Šípek P. 2018. Immature stages of three species of Inca LePeletier \& Serville, 1828 (Coleoptera: Scarabaeidae: Cetoniinae) and morphology of phytophagous scarab beetle pupa. Zootaxa 4434 (1): 65-88. https://doi.org/10.11646/zootaxa.4434.1.4

Tauzin P. \& Arnaud P. 2019. Contribution à la connaissance des genres Inca et Golinca et précisions sur la distribution des espèces (Coleoptera, Scarabaeidae, Cetoniinae). Le Coléoptériste 22 (3): 188-201.

Vanzolini P.E.1963. Problemas faunísticos do Cerrado. In: Ferri M.G. (ed.) Simpósio sôbre o Cerrado: 307-320. Ed. Universidade de São Paulo, São Paulo.

Manuscript received: 27 November 2020

Manuscript accepted: 9 February 2021

Published on: 30 April 2021

Topic editor: Nesrine Akkari

Section editor: Max Barclay

Desk editor: Natacha Beau

Printed versions of all papers are also deposited in the libraries of the institutes that are members of the EJT consortium: Muséum national d'histoire naturelle, Paris, France; Meise Botanic Garden, Belgium; Royal Museum for Central Africa, Tervuren, Belgium; Royal Belgian Institute of Natural Sciences, Brussels, Belgium; Natural History Museum of Denmark, Copenhagen, Denmark; Naturalis Biodiversity Center, Leiden, the Netherlands; Museo Nacional de Ciencias Naturales-CSIC, Madrid, Spain; Real Jardín Botánico de Madrid CSIC, Spain; Zoological Research Museum Alexander Koenig, Bonn, Germany; National Museum, Prague, Czech Republic. 